Jurnal InFestasi

Vol. 12, No.1, Juni 2016

Hal. 55 - 65

\title{
KAJIAN EMPIRIS BEBAN PAJAK TANGGUHAN DAN KEPEMILIKAN INSTITUSIONAL TERHADAP MANAJEMEN LABA
}

\author{
Reskino \\ Issan Chairul Imam
}

Universitas Islam Negeri Syarif Hidayatullah Jakarta

\begin{abstract}
This study is aimed to investigate the influence of deferred tax and institusional ownership on earning management. This research used the sample of manufactur industries listed in Indonesian Stock Exchange during 2010-2013 period. The number of manufactur industries sampled in this study were 78 companies with 4 years observation. Based on purposive sampling method, sample consist of 312 financial statement in this research. Hypothesis in this research are tested by logistic regression analytical method.

Based on sample, the result show that deferred tax negative-significantly influence to earning management and institusional ownership negative-significantly influence to earning management.
\end{abstract}

Keywords: earnings management, deferred tax expense, institusional ownership,

\begin{abstract}
Abstrak
Penelitian ini bertujuan untuk mengamati pengaruh pajak tangguhan dan kepemilikan institusional terhadap managemen laba. Sampel dalam penelitian ini adalah perusahaan manufaktur yang terdaftar di bursa efek Indonesia periode tahun 2010 - 2013. Jumlah sampel penelitian 78 perusahaan dengan periode pengamatan 4 tahun. Berdasarkan metode purposive sampling, sampel penelitian berjumlah dari 312 laporan keuangan. Pengujian hipotesis penelitian menggunakan metode analisis regresi logistik. Hasil penelitian menunjukkan bahwa pajak tangguhan memiliki pengaruh negatif dan signifikan terhadap managemen laba, dan kepemilikan institusional memiliki pengaruh negatif dan signifikan terhadap managemen laba.
\end{abstract}

\section{PENDAHULUAN}

Perusahaan harus melaporkan laporan keuangannya secara transparan dan akuntabel kepada Stake Holder's. Laporan keuangan tersebut merupakan media komunikasi yang menginfomasikan tentang posisi keuangan dan kinerja keuangan yang telah dicapai oleh suatu perusahaan pada suatu periode tertentu. Manajer sebagai pengelola yang diberi wewenang oleh pemegang perusahaan harus melaporkan pengelolaannya secara bertanggungjawab. Namun, pada kenyataannya masih banyak manajer perusahaan yang melakukan manipulasi laporan keuangan dengan tujuan meningkatkan atau menurunkan laba.

Kasus menggelembungkan laba yang pernah terjadi di Indonesia adalah pada PT Kimia Farma Tbk dimana pihak manajemen PT. Kimia Farma melakukan penggelembungan laba pada laporan keuangan tahunan 2001 sebesar Rp 32,6 milyar. Selain itu kasus manajemen laba juga terjadi pada Sinar Mas Group, Indomobil, dan Lippo Bank. Kasus manajemen laba dengan cara menurunkan laba dilakukan pada saat perusahaan harus melakukan pembayaran pajak yang tinggi, maka perusahaan membayar pajak yang rendah. Inilah yang menjadi awal permasalahan agensi antara perusahaan dengan pemerintah dikarenakan manajer cenderung selalu berusaha meminimalisir kewajiban-kewajibanya, termasuk kewajiban untuk membayar pajak dan bagi seorang manajer semakin kecil pajak yang harus dibayarkan kepada pemerintah berarti semakin kecil kewajibannya, maka dari itu, manajer akan berusaha agar laba perusahaan 
selalu kelihatan lebih rendah daripada laba yang sesungguhnya diperoleh. Oleh karena itu, manajer lebih menguasai informasi perusahaan dibandingkan dengan pemerintah (Sulistyanto, 2008:96).

Penelitian yang dilakukan oleh Philip et.al., (2003) menyatakan, bahwa beban pajak tangguhan dan akrual dapat mendeteksi manajemen laba yang dilakukan perusahaan untuk menghindari penurunan laba dan menghindari kerugian. Sedangkan penelitian yang dilakukan oleh Ulfa (2013) menemukan bahwa memang terjadi manajemen laba dengan tujuan menghindari pelaporan kerugian pada perusahaan-perusahaan yang terdaftar di BEI tahun 2009-2011 dan membuktikan bahwa beban pajak tangguhan berpengaruh positif artinya setiap kenaikan beban pajak tangguhan, maka probablilitas perusahaan melakukan manajemen laba akan mengalami peningkatan. Selanjutnya, pada penelitian Yulianti (2005), menyatakan bahwa beban pajak tangguhan dan akrual memiliki pengaruh yang positif dan signifikan terhadap probabilitas perusahaan yang melakukan manajemen laba untuk menghindari kerugian pada perusahaan yang terdaftar di BEJ tahun 1999 - 2002.

Selain beban pajak tangguhan, suatu kajian yang perlu diteliti lebih lanjut adalah kepemilikan institusional. Dengan adanya kepemilikan institusional di luar perusahaan yang mempunyai presentase besar akan melakukan pengawasan yang ketat terhadap manajemen yang ingin melakukan manajemen laba. Dengan adanya kepemilikan institusional akan mendorong manajer lebih fokus melakukan kinerja yang bagus untuk mengurangi terjadi manajemen laba.

Hal ini pernah diteliti sebelumnya oleh Tarjo (2008) yang menyatakan bahwa dominasi pemilik institusional menyebabkan manajer tidak bisa bertindak oportunistik yang cenderung menguntungkan dirinya sendiri tetapi kemungkinan merugikan pemilik. Sehingga manajer tidak bisa dengan leluasa memanipulasi angka laba yang dihasilkan perusahaan dan investor institusional berpandangan yang jauh lebih ke depan dibandingkan investor individu yang hanya fokus untuk laba sekarang. Sehingga manajer tidak bisa dengan leluasa memanipulasi angka laba yang dihasilkan perusahaan. Barus \& Setiawati (2015), melalui mekanisme kepemilikan institusional, efektivitas pengelolaan sumber daya yang dimiliki perusahaan oleh manajemen dapat diketahui dari informasi yang dihasilkan melalui reaksi pasar atas pengumuman laba. Hal ini sesuai dengan pandangan bahwa investor institusional cenderung berorientasi terhadap laba, yang memicu pihak manajemen untuk memenuhi tujuan laba dari para investor. Hal inilah yang mendorong pihak manajemen untuk melakukan manajemen laba. Selanjutnya, pada penelitian Widyastuti (2009) menyatakan bahwa dari jenis strukturnya, struktur kepemilikan institusional berpengaruh negatif terhadap manajemen laba artinya semakin kecil struktur kepemilikan institusional dalam perusahaan, maka akan menyebabkan peningkatan manajemen laba.

Berdasarkan pendahuluan di atas, maka pertanyaan yang diajukan dalam penelitian ini adalah "apakah terdapat pengaruh yang signifikan beban pajak tangguhan dan kepemilikan institusional terhadap manajemen laba?." Penelitan ini bertujuan untuk menganalisis pengaruh pajak tangguhan dan kepemilikan institusional terhadap manajemen laba.

\section{Agency Theory}

Teori keagenan menjelaskan hubungan antara owner dengan pengelola perusahaan yang mempublikasikan annual report perusahaan. Stakeholder adalah pihak yang membutuhkan informasi mengenai kondisi keuangan, kinerja perusahaan serta informasi yang mendukung prospek perusahaan dimasa yang akan datang. Manajer adalah pihak yang mengelola informasi mengenai perusahaan, baik kondisi keuangan maupun non keuangan. Pengelolaan informasi yang dipublikasikan oleh perusahaan dapat menimbulkan adanya masalah asimetri informasi karena manajer dapat mengendalikan informasi 
yang akan dipublikasikan (Jensen dan Meckling dalam Wardani, 2009).

Teori agensi mengasumsikan bahwa semua individu bertindak atas kepentingan mereka sendiri. Pemegang saham sebagai principal diasumsikan hanya tertarik kepada hasil keuangan yang bertambah atau investasi mereka di dalam perusahaan. Sedang para agen diasumsikan menerima kepuasan berupa kompensasi keuangan dan syarat-syarat yang menyertai dalam hubungan tersebut. Karena perbedaan kepentingan ini masing-masing pihak berusaha memperbesar keuntungan bagi diri sendiri. Principal menginginkan pengembalian yang sebesar-besarnya dan secepatnya atas investasi yang salah satunya dicerminkan dengan kenaikan porsi deviden dari tiap saham yang dimiliki. Agen menginginkan kepentingannya diakomodir dengan pemberian

kompensasi/bonus/insentif/remunerasi yang "memadai" dan sebesar-besarnya atas kinerjanya. Principal menilai prestasi Agen berdasarkan kemampuannya memperbesar laba untuk dialokasikan pada pembagian deviden. Makin tinggi laba, harga saham dan makin besar deviden, maka Agen dianggap berhasil/berkinerja baik sehingga layak mendapat insentif yang tinggi.

Sebaliknya Agen pun memenuhi tuntutan Principal agar mendapatkan kompensasi yang tinggi. Sehingga bila tidak ada pengawasan yang memadai maka sang Agen dapat memainkan beberapa kondisi perusahan agar seolaholah target tercapai. Permainan tersebut bisa atas prakarsa dari Principal ataupun inisiatif Agen sendiri. Maka terjadilah Creative Accounting yang menyalahi aturan, misal: adanya piutang yang tidak mungkin tertagih yang tidak dihapuskan; Capitalisasi expense yang tidak semestinya; Pengakuan penjualan yang tidak semestinya; yang kesemuanya berdampak pada besarnya nilai aktiva dalam Neraca yang "mempercantik" laporan keuangan walaupun bukan nilai yang sebenarnya. Atau bisa juga dengan melakukan income smoothing (membagi keuntungan ke periode lain) agar setiap tahun kelihatan perusahaan meraih keuntungan, padahal kenyataannya merugi atau laba turun (Error! Hyperlink reference not valid.)

\section{Pajak Tangguhan}

Beban (penghasilan) pajak tangguhan adalah jumlah beban (penghasilan) pajak tangguhan yang muncul akibat adanya pengakuan atas kewajiban atau asset pajak tangguhan (Waluyo, 2009). Pengakuan aktiva dan kewajiban pajak tangguhan didasarkan pada fakta adanya kemungkinan pembayaran pajak pada periode mendatang lebih besar atau lebih kecil (Purba, 2009).

Zain (2005) menyatakan bahwa perhitungan pajak tangguhan dengan menggunakan metode pajak tangguhan, cenderung penekanannya kepada berapa besar pajak dapat dihemat pada saat ini. Metode pajak tangguhan lebih menekankan pada pengukuran berapa besar penghematan pajak kini akibat perbedaan temporer tersebut yang dialokasikan pada periode mendatang.

\section{Kepemilikan Institusional}

Kepemilikan institusional adalah kepemilikan saham perusahaan oleh institusi keuangan seperti perusahaan asuransi, bank, dana pensiun, dan investment banking (Siregar dan Utama, 2005). Institusi merupakan sebuah lembaga yang memiliki kepentingan besar terhadap investasi yang dilakukan termasuk investasi saham sehingga biasanya institusi menyerahkan tanggung jawab kepada divisi tertentu untuk mengelola investasi perusahaan tersebut dikarenakan institusi memantau secara profesional perkembangan investasinya maka tingkat pengendalian terhadap tindakan manajemen sangat tinggi sehingga potensi kecurangan dapat ditekan (Murwaningsari, 2009) dalam Widyanti (2013).

\section{Manajemen Laba}

Menurut National Association of Certified Fraud Examiners (1993) dalam Sulistyanto (2008) mendefinisikan manajemen laba sebagai kesalahan atau kelalaian yang disengaja dalam membuat laporan mengenai fakta material atau data akuntansi sehingga menyesatkan 
ketika semua informasi itu dipakai untuk membuat pertimbangan yang akhirnya akan yang menyebabkan orang yang membacanya akan mengganti atau mengubah pendapat atau keputusannya).

Scott (2006) mendefinisikan manajemen laba sebagai pemilihan kebijakan akuntansi oleh manajer dari Standar Akuntansi Keuangan yang ada dan secara alamiah dapat memaksimalkan utilitas mereka dan atau nilai pasar perusahaan.Dari definisi yang diberikan oleh Scott bisa dijelaskan bahwa manajer mempunyai wewenang untuk memaksimalkan atau menurunkan labanya. Manajer juga bisa melakukan suatu intervensi dalam proses pelaporan keuangannya dengan maksud untuk memperoleh keuntungan pribadi.

Terdapat motivasi yang mendorong manajer untuk berperilaku oportunis yang sejalan dengan tiga hipotesis utama dalam teori akuntansi positif (Positive Accounting Theory), yaitu bonus plan hypothesis, debt covenant hypothesis dan political cost hypothesis (Watts dan
Zimmerman 1990). Dalam Teori Akuntansi Positif menjelaskan tiga hipotesis yang mendorong perusahaan melakukan manajemen laba (Barus \& Setiawati 2015) yaitu : pertama, The bonus plan hypothesis yaitu manajer perusahaan yang memiliki program bonus yang terkait dengan angka-angka akuntansi cenderung untuk memilih prosedur akuntansi yang menggeser pelaporan laba dari periode mendatang ke periode tahun berjalan (menaikkan laba yang dilaporkan sekarang ). Kedua, The debt covenant hypothesis dimana perusahaan yang terancam melanggar konvensi perjanjian hutang cenderung untuk memilih prosedur akuntansi yang menggeser pelaporan laba dari periode mendatang ke periode tahun berjalan. Ketiga, The political cost hypothesis dimana semakin besar biaya politis yang dihadapi suatu perusahaan, maka manajer cenderung untuk memilih prosedur akuntansi yang menangguhkan pelaporan laba periode mendatang ke periode tahun berjalan (menurunkan laba yang dilaporkan sekarang).

\section{Model Penelitian}

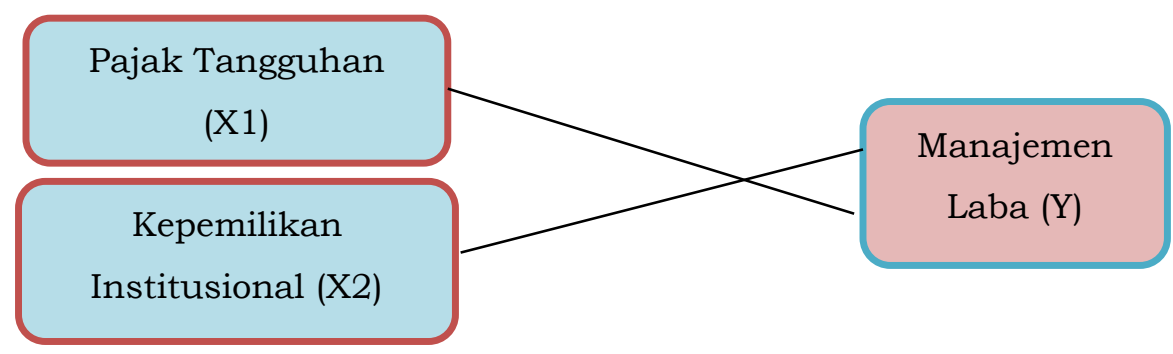

Gambar 1. Model Penelitian

Berdasarkan teori sebelumnya dan model peneitian, maka hipotesis yang ingin dibuktikan dalam penelitian ini yaitu $\mathrm{H}_{1}$ : Pajak tangguhan berpengaruh secara signifikan

\section{METODE PENELITIAN}

Penelitian ini termasuk dalam penelitian kausalitas, yaitu penelitian yang bertujuan untuk mengetahui hubungan serta pengaruh antara dua variabel atau lebih menurut Kuncoro (2003:10-11) dalam Suharso (2009:11). Populasi

\begin{abstract}
terhadap manajemen laba, dan hipotesis kedua $\left(\mathrm{H}_{2}\right)$ penelitian ini yakni Kepemilikan institusional berpengaruh secara signifikan terhadap manajemen laba.
\end{abstract}

penelitian ini adalah perusahaan manufaktur yang terdaftar di Bursa Efek Indonesia selama periode 2010-2013. Metode pengambilan sampel yang digunakan adalah purposive sampling dengan kriteria sebagai berikut : (1) Perusahaan Manufaktur yang listed di Bursa Efek Indonesia pada tahun 2010- 
2013 dan tidak delisting atau keluar dari BEI selama periode pengamatan. (2) Perusahaan tersebut sudah terdaftar di BEI sebelum 1 Januari 2010. (3) Perusahaan yang melaporkan laporan keuangannya menggunakan mata uang rupiah. (4) Perusahaan yang menerbitkan laporan keuangan yang telah diaudit oleh auditor independen dari 2010-2013. (4) Memiliki data perusahaan yang lengkap berupa laporan keuangan sesuai dengan variabel yang akan diteliti.

Data-data yang digunakan dalam penelitian ini adalah data sekunder, yaitu berupa daftar perusahaan manufaktur yang listing di Bursa Efek Indonesia (BEI) periode 2010-2013 dan laporan keuangan tahunannya selama 2010-2013. Pengumpulan data dalam penelitan ini diperoleh dari Pusat Referensi Pasar Modal (PRPM) di Bursa Efek Indonesia (BEI). Selain itu, data dan informasi lain diperoleh dari jurnal, textbook, surat kabar dan internet.

Metode statistik yang digunakan untuk menganalisis data dan menguji hipotesis yaitu dengan menggunakan statistik deskriptif dan regresi logistik dengan menggunakan bantuan perangkat lunak Microsoft Excel 2007 dan SPSS. Uji asumsi klasik dan uji hipotesis. Alasan penggunaan alat analisis regresi logistik (logistic regression) adalah karena variabel dependen bersifat dikotomi (small profit firms dan small lost firms). Menurut Uyanto (2006 : 225) menyatakan bahwa regresi logistik biner adalah regresi logistik dimana variabel depedennya berupa variabel dikotomi atau variabel biner.

Model yang digunakan untuk pengujian probabilitas beban pajak tangguhan dan kepemilikan institusional dalam mendeteksi manajemen laba adalah :

$$
\begin{aligned}
& \mathrm{EM}=\beta_{0}+\beta_{1} \mathrm{DTE}+\beta_{2} \text { INST }+\mathrm{e} \\
& \mathrm{EM}=\text { Earning Management } \\
& \beta_{0}=\text { Konstanta } \\
& \beta_{0}-\beta_{2}=\text { Koefisien Arah Regresi } \\
& \mathrm{DTE}=\text { Beban Pajak Tangguhan } \\
& \mathrm{INST}=\text { Kepemilikan Institusional } \\
& \mathrm{e}
\end{aligned}
$$

Pengukuran Variabel dalam penelitian ini yaitu (a) beban pajak tangguhan diukur dengan beban pajak tangguhan pada periode laporan keuangan dibagi dengan total aktiva pada periode sebelumnya (Deviana dan Kiswara, 2010), (b) kepemilikan institusional diukur dengan skala rasio melalui jumlah saham yang dimiliki oleh investor institusional dibandingkan dengan total (Guna dan Herawaty, 2010:60), dan (c) Manajemen laba dikategorikan 1 untuk perusahaan berada dalam range small profit firms adalah perusahaan - perusahaan yang memiliki Net Income/Market Value Equity pada range $0 \mathrm{~s} / \mathrm{d} \quad 0,06$ dan 0 untuk perusahaan berada dalam range small loss firms yaitu perusaahaan perusahaan yang memiliki yang memiliki Net Income/Market Value Equity -0.09 s/d 0 (Yulianti, 2005).

\section{PEMBAHASAN}

\section{Deskripsi Objek Penelitian}

Populasi dalam penelitian ini adalah perusahaan sektor manufaktur di Bursa Efek Indonesia (BEI) pada periode 20102013. Pengolahan data pada penelitian ini menggunakan fasilitas elektronik dengan menggunakan SPSS untuk memudahkan pengelolaan data sehingga dapat menjelaskan variabel-variabel yang diteliti. Pengambilan sampel dalam penelitian ini menggunakan metode purposive sampling pada perusahaan manufaktur yang terdaftar di Bursa Efek Indonesia 2010 sampai tahun 2013. 
Tabel 1. Proses Seleksi Sampel

\begin{tabular}{|c|c|c|c|}
\hline No & Kriteria & $\begin{array}{l}\text { Pelanggaran } \\
\text { Kriteria }\end{array}$ & Jumlah \\
\hline 1 & Perusahaan manufaktur periode 2009-2013. & & 140 \\
\hline 2 & $\begin{array}{l}\text { Terdaftar sebelum } 1 \text { Januari } 2009 \text { dan tidak } \\
\text { delesting selama periode pengamatan. }\end{array}$ & (19) & 121 \\
\hline 3 & $\begin{array}{l}\text { Perusahaan yang menggunakan mata uang } \\
\text { rupiah }\end{array}$ & $(26)$ & 95 \\
\hline 4 & $\begin{array}{l}\text { Perusahaan yang menerbitkan laporan keuangan } \\
\text { yang telah diaudit oleh auditor indenpenden }\end{array}$ & $(2)$ & 93 \\
\hline 5 & $\begin{array}{l}\text { Data variabel dependen dan indenpenden yang } \\
\text { tersedia. }\end{array}$ & $(15)$ & 78 \\
\hline \multicolumn{2}{|c|}{ Jumlah Sampel } & \multicolumn{2}{|l|}{78} \\
\hline \multicolumn{2}{|c|}{ Periode Penelitian } & \multicolumn{2}{|l|}{4} \\
\hline \multicolumn{2}{|r|}{ Total Jumlah Sampel Selama Periode Penelitian } & \multicolumn{2}{|l|}{312} \\
\hline
\end{tabular}

Sumber : data sekunder diolah

Hasil Uji Instrumen Penelitian

Hipotesis dalam penelitian ini diuji dengan menggunakan model regresi logistik (logistic regression). Tujuannya adalah untuk memperoleh gambaran yang menyeluruh mengenai variabel independen (beban pajak tangguhan dan kepemilikan institusional) terhadap variabel dependen yaitu manajemen laba.

\section{Hasil Uji Statistik Deskriptif}

Penelitian statistik deskriptif memberikan gambaran atau deskripsi suatu data yang dilihat dari nilai ratarata (mean), standar deviasi, varian, maksimum, minimum, sum, range, kurtosis, dan skewness (Ghozali, 2011:19).

Berdasarkan hasil uji deskriptif diperoleh sebanyak 312 data pengamatan (N) yang berasal dari perkalian antara jumlah perusahaan sampel $(78$ perusahaan) dengan periode penelitian (4 tahun, dari tahun 2010 sampai 2013). Statistik deskriptif dari masing-masing variabel penelitian menunjukkan nilai minimum sebesar $-0,08$, nilai maksimum sebesar 0,23 dengan nilai rata-rata sebesar 0,013 dan standar deviasinya sebesar 0,01828 .

$$
\text { Hasil analisis dengan }
$$

menggunakan statistik deskriptif terhadap variabel kepemilikan institusional (INST) menunjukkan nilai minimum sebesar 0,30, nilai maksimum sebesar 0,99 dengan nilai rata-rata sebesar 0,7190 dan standar deviasinya sebesar 0,17590. Kemudian hasil analisis dengan menggunakan statistik deskriptif terhadap variabel manajemen laba atau earning management (EM) menunjukkan nilai minimum sebesar 0 , nilai maksimum sebesar 1 dengan nilai ratarata 0,89 dan standar deviasinya sebesar 0,308 .

\section{Hasil Uji Hipotesis Penelitian}

Karena variabel dependen bersifat dummy (small profit firms dan small loss firms), maka pengujian terhadap hipotesis dilakukan dengan menggunakan uji regresi logistik. Tahapan dalam pengujian dengan menggunakan uji regresi logistik dapat dijelaskan sebagai berikut (Ghozali, 2011:340).

Hasil Uji Keseluruhan Model (Overall Model Fit)

Pengujian dilakukan dengan membandingkan nilai -2 Log Likehood (2LL) pada awal (Block Number $=0$ ) dengan nilai -2 Log Likehood (-2LL) pada akhir (Block Number $=1$ ). Nilai -2LL awal adalah sebesar 210.648. Setelah dimasukkan kedua variabel indenpenden, maka nilai -2LL akhir mengalami penurunan menjadi 183.396. Penurunan Likehood (-2LL) ini menunjukkan model regresi yang lebih baik atau dengan kata lain model yang dihipotesiskan fit dengan data.

Hasil Uji Koefisien Determinasi (Nagelkerke R. Square) 
Besarnya nilai koefisien determinasi pada model regresi logistik ditunjukkan oleh nilai Nagelkerke $R$ Square. Nilai Nagelkerke $R$ Square adalah sebesar 0,170 yang berarti variablitas variabel dependen yang dapat dijelaskan oleh variabel independen adalah sebeasar $17 \%$, sedangkan sisanya $83 \%$ dijelaskan oleh variabel - variabel diluar model penelitian, seperti perencanaan pajak, arus kas operasi perusahaan, return on asset, return on equity, net profit margin, dan ukuran perusahaan. Tabel 2 berikut menyajikan hasil uji koefisien determinasi (Nagelkerke $R$ Square):

Tabel 2. Koefisien Determinasi

Model Summary

\begin{tabular}{llll}
\hline Step & -2 Log likelihood & $\begin{array}{l}\text { Cox \& Snell R } \\
\text { Square }\end{array}$ & $\begin{array}{l}\text { Nagelkerke R } \\
\text { Square }\end{array}$ \\
\hline 1 & $183.396^{\mathrm{a}}$ & .084 & .170 \\
\hline
\end{tabular}

a. Estimation terminated at iteration number 6 because parameter estimates changed by less than .001 .

Hasil Uji Kelayakan Model Regresi

Kelayakan model regresi dinilai dengan menggunakan Hosmer and Lemeshow's Goodness of Fit Test. Pengujian menunjukkan nilai Chi-square sebesar 5.918 dengan signifikansi (p) sebesar 0.656. Berdasarkan hasil tersebut, karena nilai signifikansi lebih besar dari 0,05, maka model mampu memprediksi nilai observasinya.

Hasil Uji Multikolinieritas.

Uji Multikolonieritas bertujuan untuk menguji apakah regresi ditemukan adanya korelasi antar variabel bebas (indenpenden). Model regresi yang baik adalah regresi dengan tidak adanya gejala korelasi yang kuat diantara variabel bebasnya.Pengujian ini menggunakan matriks korelasi antar variabel bebas untuk melihat besarnya korelasi antar variabel indenpenden. Hasil uji Multikolearitas dalam penelitian ini diperoleh hasil tidak ada nilai koefisien korelasi antar variabel yang nilainya lebih besar dari 0,90, maka tidak ada gejala multikolinieritas yang serius antar variabel bebas (Ghazali 2011:105).

Hasil Matriks Klasifikasi

Matriks klasifikasi menunjukkan kekuatan prediksi dari model regresi untuk memprediksi kemungkinan terjadinya manajemen laba pada sebuah perusahaan.

Tabel 3. Hasil Identifikasi Prediksi Klasifikasi

Classification Table

\begin{tabular}{|c|c|c|c|c|c|}
\hline & & & $\begin{array}{l}\mathrm{Pr} \\
\mathrm{Er}\end{array}$ & & \\
\hline \multicolumn{3}{|c|}{ Observed } & 0 & 1 & \\
\hline \multirow[t]{2}{*}{ Step 1} & EM & 0 & 6 & 27 & 18.2 \\
\hline & & 1 & 0 & 279 & 100.0 \\
\hline & Over & erce & & & 91.3 \\
\hline
\end{tabular}

Kekuatan prediksi dari model regresi untuk memprediksi kemungkinan perusahaan mengalami small profit firms (1) adalah sebesar 100\%. Hal ini menunjukkan bahwa dengan menggunakan model regresi yang digunakan, terdapat sebanyak 279 sampel (100\%) yang diprediksi akan mengalami manajemen laba dari total 279 sampel yang mengalami manajemen laba. Kekuatan prediksi model perusahaan yang mengalami small lost 
firms (0) adalah sebesar $18,2 \%$ yang berarti bahwa dengan model regresi yang digunakan ada 6 sampel $(18,2 \%)$ yang diprediksi tidak melakukan manajemen laba dari total 33 perusahaan yang tidak melakukan manajemen laba. Dapat disimpulkan bahwa kekuatan prediksi dari model regresi sebesar $91,3 \%$.

Hasil Uji Regresi Logistik

Model regresi logistik yang terbentuk disajikan pada table 4 , sebagai berikut:

Tabel 4. Hasil Uji Koefisien Regresi Logistik

Variables in the Equation

\begin{tabular}{cccccccc}
\hline & & B & S.E. & Wald & df & Sig. & Exp(B) \\
\hline Step 1 & DTE & -46.855 & 14.576 & 10.333 & 1 & .001 & .000 \\
& INST & -3.361 & 1.327 & 6.417 & 1 & .011 & .035 \\
& Constant & 4.848 & 1.063 & 20.794 & 1 & .000 & 127.461 \\
\hline
\end{tabular}

a. Variable(s) entered on step 1: DTE, INST.

Sumber: Pengolahan Data SPSS

Hasil pengujian terhadap koefisien regresi logistic menghasilkan model berikut ini:

$E M=4.848-46.855 \mathrm{DTE}-3.361 \mathrm{INST}$

\section{Pengaruh beban pajak tangguhan (DTE) terhadap manajemen laba (EM).}

Variabel beban pajak tangguhan menunjukkan koefisien negatif sebesar 46.855 dengan tingkat signifikansi $(\rho)$ sebesar 0.001 . Karena tingkat singnikansi $(\rho)$ lebih kecil dari $a=5 \%$, maka hipotesis ke - 1 (H1) diterima. Penelitian ini berhasil membuktikan bahwa beban pajak tangguhan berpengaruh terhadap manajemen laba. Hasil penelitian ini mendukung hasil penelitian sebelumnya yang dilakukan oleh Philip et.al., (2003) Yulianti (2005) dan Ulfa (2013). Namun tdak sejalan dengan penelitian yang dilakukan oleh (Barus \& Setiawati 2015) yang menemukan bahwa variabel beban pajak tangguhan tidak berpengaruh signifikan terhadap manajemen laba. Hal ini dikarenakan adanya kemungkinan bahwa salah satu penyebab timbulnya beban pajak tangguhan adalah dari kegiatan tax planning yang dilakukan oleh perusahaan.Kegiatan tax planning yang dilakukan perusahaan hanya mempengaruhi penghasilan kena pajak.Oleh sebab itu, beban pajak tangguhan bisa saja timbul bukan karena kesengajaan yang dilakukan oleh pihak manajemen perusahaan untuk melakukan manajemen laba, tetapi bisa saja karena kegiatan tax planning.
Hasil penelitian ini menunjukkan bahwa semakin besar beban pajak tangguhan maka kemungkinan sebuah perusahaan mengalami manajemen laba akan semakin menurun. Hal ini sesuai dengan teori yang dikemukakan oleh (Watt dan Zummerman, 1986, 1990 dalam Widyaningsih dan Purnawati, 2012:235) bahwa alasan penghematan atau penundaan pajak (pajak tangguhan) melalui kecenderungan perusahaan mengurangi laba yang dilaporkan merupakan dari teori akuntansi positif yaitu Political Cost Hypothesis sehingga beban pajak tangguhan dapat mempengaruhi manajemen laba sebagai motivasi penghematan pajak. Political Cost Hypothesis adalah perusahaan cenderung memilih dan menggunakan metode-metode akuntansi yang dapat memperkecil atau memperbesar laba yang dilaporkannya.

Semakin besar beban pajak tangguhan semakin besarnya kemungkinan perusahaan akan mengurangi laba perusahaan dengan tujuan untuk penghematan dalam pembayaran pajak. Hal ini membuat manajemen memanfaatkan celah untuk melakukan manipulasi besarnya beban pajak tangguhan yang dimiliki dan juga memberikan keuntungan tersendiri bagi agent (manajemen) untuk mendapatkan bonus atas pencapaian kinerja yang bagus.

Pengaruh kepemilikan institusional (INST) terhadap manajemen laba (EM). 

Variabel beban pajak tangguhan
menunjukkan koefisien negatif sebesar 3.361 dengan tingkat signifikansi $(\rho)$ sebesar 0.011. Karena tingkat singnikansi $(\rho)$ lebih kecil dari $\mathrm{a}=5 \%$, maka hipotesis ke - 2 (H2) diterima.

Hasil penelitian ini membuktikan bahwa kepemilikan institusional berpengaruh negatif terhadap manajemen laba. Hasil penelitian ini mendukung hasil penelitian sebelumnya yang dilakukan oleh Tarjo (2008) dan Widyastuti (2009) tapi tidak sejalan dengan penelitian yang dilakukan oleh Barus \& Setiawati, 2015; Husni, 2010 yang menemukan bahwa Variabel kepemilikan institusional berpengaruh positif dan signifikan terhadap manajemen laba melalui mekanisme kepemilikan institusional, efektivitas pengelolaan sumber daya yang dimiliki perusahaan oleh manajemen dapat diketahui dari informasi yang dihasilkan melalui reaksi pasar atas pengumuman laba. Hal ini sesuai dengan pandangan bahwa investor institusional cenderung berorientasi terhadap laba, yang memicu pihak manajemen untuk memenuhi tujuan laba dari para investor. Hal inilah yang mendorong pihak manajemen untuk melakukan manajemen laba.

$$
\text { Hasil penelitian ini juga }
$$

menunjukkan bahwa semakin tinggi persentase saham yang dimiliki oleh kepemilikan institusional, maka akan semakin mengurangi tindakan manajemen laba yang dilakukan perusahaan tersebut. Dengan adanya kepemilikan institusional berpeluang melakukan praktek manajemen laba semakin kecil. Sebaliknya, Jika presentase kepemilikan saham yang rendah, maka hanya memiliki sedikit dorongan untuk melakukan pengawasan terhadap tindakan oleh manajer maka dipastikan akan berpeluang besar melakukan praktek manajemen laba. Tindakan yang dilakukan oleh pihak kepemilikan institusional dapat mendorong manajer untuk lebih fokus terhadap kinerja perusahaan menjadi lebih bagus sehingga akan mengurangi terjadinya perilaku opportunistic atau kepentingan diri sendiri. Oleh karena itu dengan adanya kepemilikan institusional akan dapat mampu mengawasi lebih efektif bagi perusahaan.

\section{PENUTUP}

\section{Simpulan}

Pajak tangguhan secara statistik berpengaruh negatif secara signifikan terhadap manajemen laba selama empat tahun pengamatan (2010-2013). Hasil penelitian ini mendukung hasil penelitian yang dilakukan oleh Philips et al (2003), Yulianti (2005), dan Ulfa (2014). yang menyatakan bahwa beban pajak tangguhan mempunyai pengaruh terhadap manajemen laba.

Kepemilikan institusional secara statistik berpengaruh negatif secara signifikan terhadap manajemen laba selama empat tahun pengamatan (20102013). Hasil penelitian ini mendukung oleh Widyastuti (2009), dan Tarjo (2008) menyatakan bahwa kepemilikan institusional mempunyai pengaruh terhadap manajemen laba.

\section{Saran}

Penelitian mengenai manajemen laba dimasa yang akan datang diharapkan memberikan hasil penelitian yang lebih berkualitas, dengan mempertimbangkan saran di bawah ini: (1) Menambah variabel independen maupun variabel control lebih banyak, seperti perencanaan pajak (TP), arus kas operasi perusahaan $(\mathrm{CFO})$, return on asset $(\mathrm{ROA})$, return on equity (ROE), net profit margin (NPM), ukuran perusahaan (SIZE) dan sebagainya. (2) Penelitian dapat mempertimbangkan penggunaan seluruh perusahaan yang terdaftar di BEI sebagai populasi penelitian serta menambah periode pengamatan yang lebih panjang untuk memperbanyak jumlah data perusahaan manufaktur yang digunakan dalam penelitian

\section{DAFTAR PUSTAKA}

Andromeda, Donny Arlanda., 2008. "Analisis Pengaruh Manajemen Laba Terhadap Return Saham pada Perusahaan Manufaktur di BEJ yang Diaudit oleh Kantor Akuntan Publik Berskala Besar dan Kantor Akuntan Publik Berskala Kecil". 
Tesis Program Magister Universitas Dipenogoro.

Barus, A. C., \& Setiawati, K., 2015. Pengaruh Asimetri Informasi, Mekanisme Corporate Governance, dan Beban Pajak Tangguhan Terhadap Manajemen Laba, 5.

Christiani, I. \& Nugrahanti, Y.W., 2014. Pengaruh Kualitas Audit Terhadap Manajemen Laba. , 16(1), pp.52-62.

Deviana, Birgita dan Endang Kiswara., 2010 "Kemampuan Beban Pajak Tangguhan dan beban pajak kini dalam deteksi manajemen laba pada saat seasoned equity offerings".Universitas Diponegoro.

Guna, Welvin I dan Arleen Herawaty., 2010. "Pengaruh Mekanisme Good Corporate Governance, Independensi Auditor, Kualitas Audit dan Faktor Lainnya Terhadap Manajemen Laba".Jurnal Bisnis dan Akuntansi, Vol. 12, No. 1.

Ghozali, Imam.,2011. "Aplikasi Analisis Multivariate dengan Program IBM SPSS 19 Edisi 5", Badan Penerbit Universitas Diponogoro, Semarang.

Husni, R., 2010., Pengaruh Mekanisme Good Corporate Governance, Leverage dan Profitabilitas terhadap Manajemen Laba (Studi Empiris Perusahaan Property dan Real Estate yang Terdaftar di Bursa Efek Indonesia tahun 2008 - 2010)

http://www.kesimpulan.com/2009/04/p raktek-manajemen-laba.html

http://msa15.blogspot.co.id/2012/02/te ori-keagenan-dan-earningmanagement.html

Indiriani, Rini., 2010 "Pengaruh Kualitas Pelaporan Keuangan Terhadap Informasi Asimetri". Simposium Nasional Akuntansi XIII, Purwokerto.

Kusumastuti, Meirina Cherta dan Soni Agus Irwandi. 2012 "Investigasi Empat Faktor Kontingensi Sebagai Variabel Moderating Terhadap Partisipasi Pemakai dan Kepuasan Pemakai dalam Pengembagan Sistem Informasi". The Indonesian Accounting Review, Volume 2, No. 2, July 2012.

Philips, Pincus, dan S.O. Rego., 2003. "Earning Management : New Evidence Based on Deffered Tax
Expense". The Accounting Review. No. 78 .

Purba, Marisi., 2009. "Akuntansi Pajak Penghasilan". Graha Ilmu, Yogyakarta.

Saputra, Mulia., 2010."Pengaruh Corporate Governance Terhadap Nilai Perusahaan di Bursa Efek Indonesia, Jakarta" Journal of Indonesian Applied Economics, Vol.4 No.1 Mei 2010, Hal 81-92.

Scott,William R., 2003. Financial Accounting Theory. New Jersey: Prentice Hall Inc.

Siregar, Silvia Veronica N.P., dan Siddharta Utama., 2005. "Pengaruh Struktur Kepemilikan, Ukuran Perusahaan dan Praktik Corporate Governance terhadap Pengelolaan Laba (Earnings Management)". SimposiumNasional Akuntansi (VIII) Solo.

Sri Sulistyanto.,2008. "Manajemen Laba Teori dan Model Empiris", PT. Grasindo, Jakarta.

Suharso, Puguh., 2009. "Metode Penelitian Kuantitatif Untuk Bisnis : Pendekatan Filosofi dan Praktis", PT. Malta Pritindo, Jakarta.

Tarjo., 2008."Pengaruh Konsentrasi Kepemilikan Institusional dan Leverage Terhadap Manajemen Laba, Nilai Pemegang Saham serta Cost of Equity Capital (CEC)".Universitas Trunojoyo Bangkalan Madura.

Ulfah, Yana., 2013 "Pengaruh Beban Pajak Tangguhan dan Perencanaan Pajak Terhadap Praktik Manajemen Laba". Simposium Nasional Perpajakan 4 Madura.

Uyanto, Stanislaus S., 2006."PedomanAnalisis Data dengan SPSS"Yogya”, Graha Ilmu.

Waluyo., 2009. "Akuntansi Pajak", Salemba Empat, Jakarta

Wardani, Rr. Puruwita., 2009. "FaktorFaktor yang Mempengaruhi Luas Pengungkapan Sukarela". Jurnal Akuntansi dan Keuangan Vol. 14, No. 1, Mei 2012

Watts, R. L., and Zimmerman, J. L., 1990. "Positive Accounting Theory: A Ten Year Perspective," The Accounting Review. 65(1), 131-158. 
Widyastuti, Tri., 2009. "Pengaruh Struktur Kepemilikan dan Kinerja Keuangan Terhadap Manajemen Laba: Study Empiris Pada Perusahaan Manufaktu dii BEI", Jurnal Maksi,Vol.9.
Yulianti., 2005. "Kemampuan Beban Pajak Tangguhan Dalam Mendeteksi Manajemen Laba". Universitas Indonesia, 2005.

Zain, Mohammad., 2005. "Manajemen Perpajakan". Salemba Empat, Jakarta. 